\title{
The Implementation of Team Games Tournament to Improve Students' Problem- Solving Skill (Quasi Experiment With Blended Learning Strategy)
}

Rani Sofya, Universitas Negeri Padang, Padang, Indonesia, $\square$ (e-mail) sofyarani.sofya@gmail.com

\begin{abstract}
This research is a quasi-experimental research on Introduction to Accounting 1 course with the aim of finding the influence of the implementation of team games tournament method with the use of blended learning on students' problem-solving skill. The research data were tested and processed with Microsoft Excel and SPSS 17 for Windows. Before the hypothesis testing was done, a classical assumption test was employed in the form of normality and homogenity test. To find out the normality of data distribution, the Kolmogrov-Smirnov test was utilized, with the criteria of distributed data perceived as normal if the significance value is greater than 0.05 . The normality test shows that the data are normally distributed. The homogenity test of variance between groups used the Levene's Test of Equality of Error Variances. The students' problem-solving ability is found to be increased based on the average pretest score of 59.66 and the average posttest score of 82.41 . The hypothesis test was done by using the t-test, and the results indicate that implementation of Teams Games Tournament method has a significant influence on the problem-solving ability of the Introduction to Accounting 1 students. Based on the result of this research, it is recommended that the lecturers of Introduction to Accounting 1 course apply this method as one of the alternatives to improve students' problem-solving skill.
\end{abstract}

Keywords: team games tournament and problem solving skill

\section{Introduction}

The development of learning technology is a facility to improve the achievement of learning objectives. One of the technological advances that have a significant impact and change the implementation strategy of learning is internet access. Through the availability of internet access learning resources can be accessed by learners without having to go through face-to-face meetings in the classroom. One way of distance learning is through elearning facilities.

Elearning as part of Learning Management System that serves as a place to teach the learning resources for learners. Learners should take an active role in accessing and learning the material that has been sent to the elearning by the teacher. While the teacher should be able to design a learning that can grow student skills. Designed Elearning is expected to foster high-level thinking skills such as critical thinking and problem solving.

Problem-solving skill is a skill that must be owned by every individual, especially learners. Various studies indicate that the inability to deal with and solve problems results in learners who act irrationally whenever they are facing a problem. The ability to solve a problem needs to be trained so that learners do not give up easily on the problems that they face. Through the learning process, learners can practice the ability to solve the problem. Baroody in Dahlan (2011) defines problems as a puzzling situation, in which one is interested to know the solution, but its resolution strategy is not necessarily available. A problem must contain (1) the desire to know; (2) the absence of a clear means of obtaining a solution; and (3) the effort to solve it. The steps of problem-solving commonly used is the one according to Polya in (Masrutollail, 2013) which include: (1) understanding the problem, (2) developing the problem-solving plan, (3) implementing a problem-solving plan, and (4) re-checking. Furthermore, there are three conditions that categorize a problem as a problem based on Schoen in 
(Sugiman, 2009). First, it is a problem if the procedure to solve it is unknown. Second, it is a problem if the problem is in the same level of thinking and knowledge of the students since the problem that is too easy or otherwise too difficult will discourage the students. Third, it is a problem if students have the intention to solve it.

The study of accounting provides students with skills and knowledge that also requires students to be able to solve problems. The financial report as the output of the accounting process is the result of a long process of recording in accounting. Students who sudy accounting must have the ability to solve accounting problems as well as mathematic problems. Accounting requires the ability to not only solve problems in the form of mathematical problems but also a more complex form of analysis and numbers accuracy, all of which has its own meaning and influence.

Introduction to Accounting 1 is a basic course and a prerequisite for the next course. The Introduction to Accounting 1 class should be implemented with meaningful learning process and should be able to motivate students to master the materials. Lessons in accounting are usually conducted in expository and drill methods by lecturers in universities. The lessons that are delivered through this the exposure are thought to be less challenging and less motivating by the students, and this affects their problem-solving skills.

Based on interviews with several lecturers of Introduction to Accounting 1, it was found that the ability of students of Introduction to Accounting 1 in solving the problems of accounting is limited to a certain knowledge. The ability of the students to solve complex problems or cases is still very limited. To improve their problem-solving skills, students must be trained to solve the problems that challenge their critical thinking.

A learning process should be able to foster students' self-confidence, competitiveness, and problem-solving skill. One method that can be selected is the cooperative method of Team Games Tournament. Team Games Tournament method is a learning method that provides opportunities for students to complete tasks or cases in groups and in an atmosphere of a tournament. The sample or cases given to students in the learning process will encourage students to have the ability to solve problems.

Team Game Match is originally developed by David De Vries and Keath Edward (1995). TGT is a type of cooperative learning that places students in 5 to 6 member study groups that have different abilities, sex and ethnicity or race. The teacher gives a worksheet to each group. The assigned tasks are done together with members of the group. If any of the group members are not familiar with the assigned task, then the other group members are responsible for providing answers or explaining it, before asking the questions to the teacher.

1. The Components of Cooperative Learning of Teams Games Tournaments (TGT) According to Slavin (2008), there are five main components of cooperative learning of Teams Games Tournaments (TGT), which are:

a. Class Presentation

The class presentation in Cooperative Learning of Teams Games Tournaments (TGT) is similar to the usual teaching or classical teaching method. However, the teaching is more focused on the material being discussed.

b. Teams

The teams are comprised of 4-5 members representing the mix of various diversities in the classroom, such as academic ability, gender, ethnic, and race.

c. Games

The questions in games are structured and designed from the material relevant to the lesson presented to test the knowledge of each group.

d. Competitions / Tournaments

The tournament is composed of several games. The steps and activities of cooperative learning of Teams Games Tournaments (TGT) are as follows: 
1) The steps of cooperative learning of TGT are in a sequence of classical arrangement, study group, academic tournaments, team rewards and transfer or bumping.

2) The lesson begins, and then the teacher announced to all students that he will implement cooperative learning of TGT and students are asked to move their chair to form a team table.

3) The activities in the tournament are competitions on the tournament table from 3-4 students from different teams with equal ability. At the start of the tournament, the table setting is announced to the students.

4) At the end of the round the winner gets one numbered card, the losing challenger returns the card in his hand (if there is one).

5) With a model that prioritizes group work and the ability to unite the different levels of ability, students will be able to learn cognitive, affective and psychomotor values together with their peers.

The method of Team Game Tournament is implemented in the learning process of Introduction to Accounting 1 with the use of blended learning (Rusman et al., 2013) revealed that blended learning is a learning method that combines two or more methods or approaches in learning to achieve the objectives of the learning process. Blended learning is an innovative concept that embraces the advantages of both traditional teaching in the classroom and ICT supported learning including both offline learning and online learning (Lalima, 2017). Hubackova a \& a (2016) blended learning is a combination of the contact teaching with a teacher and of a self-contained preparation using on-line education. Fadde \& Vu (2014) defined Blended Learning is an individual courses that blend oncampus F2F meetings with LMS-based asynchronous online instructional activities. We can implement blended learning is a combination between face to face with elearning.

Blended learning is one of the learning implementation strategies that can be chosen by teachers in this digital era. Allan \& Seaman (2013) divided Type of Course be four groups such as

Table 1 Type of Course

Proportion of Content Delivered Online Type of Course Typical Description

\begin{tabular}{lll}
\hline $0 \%$ & Traditional & $\begin{array}{l}\text { Course where no online technology } \\
\text { used - content is delivered in writing } \\
\text { or orally. }\end{array}$ \\
\hline 1 to $29 \%$ & Web Facilitated & $\begin{array}{l}\text { Course that uses web-based } \\
\text { technology to facilitate what is } \\
\text { essentially a face-to-face course. May } \\
\text { use a course management system } \\
\text { (CMS) or web pages to post the } \\
\text { syllabus and assignments. }\end{array}$ \\
& Blended/Hybrid & $\begin{array}{l}\text { Course that blends online and face-to- } \\
\text { face delivery. Substantial proportion } \\
\text { of the content is delivered online, } \\
\text { typically uses online discussions, and } \\
\text { typically has a reduced number of } \\
\text { face-to-face meetings. }\end{array}$ \\
& & $\begin{array}{l}\text { A course where most or all of the } \\
\text { content is delivered online. Typically } \\
\text { have no face-to-face meetings. }\end{array}$ \\
\hline $80+\%$ & Online &
\end{tabular}

Source : Allen and Seaman (2013)

Blended learning method will provide more varied learning facilities for students. In this study, blended learning was implemented in face to face meetings in the classroom as well as in the form of 
independent tasks online. The face-to-face lectures are conducted in the classroom by applying the Team Games Tournament method, whereas the utilization of e-learning was designed through online learning which contained learning media that can be accessed in the form of powerpoint slides, individual and group quiz and group tasks that are integrated with the tournament on face-to-face lectures. Success of blended learning depends not only on the quality of the course and the virtual environment but also on the grade to which the students are prepared to work in their virtual study environment (Hubackova a \& a, 2016). The application of various methods and learning media will give maximum results on the learning outcome.

\section{Methods}

This research is a quasi-experimental research that uses two class groups as the sample: the experimental class and the control class. The design of this study used pre-test and post-test with a randomized control group. The research design chart can be seen in Table 2 below.

Table 2 Design of pre-test and post-test treatments with a group of randomized controller

\begin{tabular}{llll}
\hline Group & Pre -Test & Independent Variable & Post-Test \\
\hline R) E & $\mathrm{Y}_{1}$ & $\mathrm{X}$ & $\mathrm{Y}_{2}$ \\
\hline (R) P & $\mathrm{Y}_{1}$ & - & $\mathrm{Y}_{2}$ \\
\hline
\end{tabular}

This research was conducted at Faculty of Economics Universitas Negeri Padang with the population is all students of Faculty of Economics. The sample class was determined by the researchers based on the pretest result of the students. The classes that are sampled are classes that have balanced pretest results and have the same initial ability (Purposive Sampling). The sample in this research is 2 classes, one class as the experimental class with as many as 29 students and one class as the control class with as many as 21 students. The instruments used in this study consist of:

1. Test Problem

The test questions are designed to gain information about students' problem-solving ability. The test problem is in the form of open-ended questions which has been validated by the expert.

2. Interview

The interview is conducted with the students to know the students' responses to the implementation of Team Games Tournament method.

3. Documentation

The documentation is in the form of photos or videos of the face-to-face lectures.

The research data were analyzed to provide data description and hypothesis testing. The measurement of students' problem-solving skill is by using the Polya model. To measure students' problem-solving skills, an open-ended test was employed. The open-ended test is designed to assess the problem-solving skill of the students in accordance with the Polya steps in(Masrutollaily, 2013), which include: (1) understanding the problem, (2) preparing the problem-solving plan, (3) implementing the problem-solving plan, and (4) re-checking. The test result of the student problemsolving ability is in the range 0-100 value. The percentage of students' abilities in each category at the problem-solving stages is based on the Polya model, and it can be determined using the following formula:

$$
P i=\frac{n i}{N i} x 100 \%
$$


In which:

$\mathrm{Pi}=$ the percentage of students in each skill level

$\mathrm{ni}=$ the number of students in each skill level

$\mathrm{N}=$ the number of students taking the test

$\mathrm{i}=$ high, medium, low level of capability

The testing was done in two stages, the assumption test and the hypothesis testing. The assumption test was done to test the normality of data distribution and the homogenity of data variance of the dependent variable. The testing of the research hypothesis requires the fulfillment of assumptions as the test analysis requirements to conclude hypothesis testing. To test the normality of data distribution, the Kolmogrov-Smirnov test was done with the criteria of normally distributed data of a significance value greater than 0.05 . The result of normality test using Kolmogrov-Smirnov test shows that the data are normally distributed, as seen in Appendix 9. The homogenity test of variance between groups used the Levene's Test of Equality of Error Variances (Irianto, 2010).

The instruments in this study only use the test instrument, which is an open-ended test to measure the problem-solving ability of Accounting students. The N-Gain data is calculated by using the normalized gain by F W Gery in (Bao, 2006), which:

$$
\text { Normalized Gain Score }=\frac{\text { Posttest Score }- \text { Pretest Score }}{\text { Maximum Score }- \text { Pretest Score }}
$$

The hypothesis testing of this research data used the $t$-test analysis. The test of the null hypothesis was performed at a significance level of $5 \%(\alpha=0.05 \%)$. All statistical analysis used SPSS 17 for Windows and Microsoft Excel 2007.

\section{Results and Discussion}

\section{Results}

Descriptive statistics of pretest and posttest results of the experimental class are presented in Table 3 below:

Table 3 Descriptive Statistics of Pretest and Posttest Results of Experimental Class

\begin{tabular}{|c|c|c|c|c|c|c|c|c|c|}
\hline & $\mathrm{N}$ & Minimum & Maximum & Sum & Mean & $\begin{array}{l}\text { Std. } \\
\text { Deviation }\end{array}$ & Variance & Median & Modus \\
\hline Pretest & 29 & 10 & 85 & 1730 & 59.66 & 18.319 & 335.591 & 65 & 85 \\
\hline Posttest & 29 & 40 & 100 & 2390 & 82.41 & 15.878 & 252.108 & 85 & 100 \\
\hline $\begin{array}{l}\text { Valid } \mathrm{N} \\
\text { (listwise) }\end{array}$ & 29 & & & & & & & & \\
\hline
\end{tabular}

The pretest and posttest results illustrated in Table 3 indicate that there is a considerable increase in the students' problem-solving ability in the experimental class, with the results on pretest indicate that the students' initial ability is still at an average score of 59.66 and it rises to 82.41 , indicating a very good number for the achievement of learning outcomes that demand students' problem-solving ability.

Based on the analysis requirements test, it is concluded that each data group is normally distributed and is homogeneous. The hypothesis test is in accordance with data analysis techniques using the t-test. 
Hypothesis:

The implementation of Teams Games Tournament method conducted with blended learning approach has a significant influence on the problem-solving ability of Introduction to Accounting 1 students of Faculty of Economics, Universitas Negeri Padang.

Table $4 \mathrm{t}$-Test Results of Hypothesis with Paired Sample Test

\begin{tabular}{lccccc}
\hline Data & Mean & Std.deviation & Significance & $\begin{array}{l}\text { Gain } \\
\text { Score }\end{array}$ & Conclusion \\
\hline Pretest & 59.66 & 18.319 & 0.000 & 0.5812 & $\mathrm{H}_{0}$ is rejected \\
\hline
\end{tabular}

The result of t-test shows that the value of Sig $0.000<0.05$, which indicates that there is a significant difference between the pretest and posttest results that affect the students' problem-solving ability.

\section{Discussion}

The result of the statistical test with the t-test shows that by implementing Teams Games Tournament method, the students' problem-solving ability in the experimental class has increased. The increase is quite significant. The problems need to be solved require students to solve them through the stages of problem-solving proposed by Polya in (Masrutollaily, 2013), namely: (1) understanding the problem, (2) preparing a problem-solving plan, (3) implementing the problemsolving plan, and (4) re-checking.

According to Arends in (Trianto, 2009), "it is strange that we expect students to learn yet seldom teach then about learning, we expect students to solve problems yet seldom teach then about problem-solving." In their teaching, teachers always demand students to learn and rarely provide lessons on how to learn. Teachers also demand students to solve problems, but they rarely teach students how to solve problems. The lessons being taught should familiarize students with how to solve the problems.

Team Games Tournament method that has been implemented shows that training students to work in teams and compete in face-to-face and online meetings can foster students' problem-solving skills. Quizzes are given with various levels of difficulty ranging from a simple to more complex level to challenge students.

Lectures conducted in blended learning provides an opportunity for students to learn independently as much as 1 credit through online or e-learning. Face-to-face lectures are held for 2 credits with the lecturers in the form of lectures, discussions, practices and team quizzes. Student participation becomes an important part of group work since they have to compete and each student must actively participate to contribute positively rather than to discourage the group.

\section{Conclusions}

Based on the statistical test that has been done, it is concluded that the implementation of Team Games Tournament method conducted in blended learning has a significant influence on students' problem-solving ability of Introduction to Accounting 1 course in Faculty of Economics, Universitas Negeri Padang. The problem-solving ability of the students who learn with Team Games Tournament method is higher than the students who learn with the conventional learning model. Therefore, it is recommended that:

1. This method to be utilized in the classroom as an alternative method of learning in Introduction to Accounting 1 course.

2. Other researchers to test this method in other courses of similar nature so that the effectiveness of this method in improving students' solving problem can be tested again. 
3. Further research may include other variables in this type of research to provide a more complex description of the effectiveness of this method as well as other factors that affect students' ability.

\section{Acknowledgments}

Thanks are due to Rector of Universitas Negeri Padang, Prof. Ganefri and The Dean of Economics Faculty Dr. Idris, M.Si, have supported us to participate in this conference.

\section{References}

Allan, I. E., \& Seaman, J. (2013). Changing course: ten years of tracking online education in the united states. Babson Survey Research Group \& Quahog Research Group.

Bao, L. (2006). Theoritical Comparisons of average normalized gain calculations. Physic Education Research, 917-922.

Dahlan, J. (2011). Materi Pokok Analisis Kurikulum Matematika. Jakarta: Universitas Terbuka.

Fadde, P., \& Vu, P. (2014). Blended online learning: challenges and misconceptions. P Lowenthal, CS York and J C Richardson (Eds), 33-48.

Hubackova a, S., \& a, I. S. (2016). Evaluation of blended learning . Procedia- Sosial and Behavioral Sciences , 551-557.

Irianto, A. (2010). Statistik Konsep Dasar dan Aplikasinya. Jakarta: Prenada Media.

Lalima, K. L. (2017). Blended Learning: an inovative approach. Universal Journal of Education Research, 129-136.

Rusman, et al. (2013). Pembelajaran Berbasis Teknologi Informasi dan Komunikasi . Bandung: Raja Grafindo.

Slavin, R. E. (2008). Cooperative Learning Teori Riset dan Praktik. Bandung: Nusa Media.

Sugiman. (2009). Pemecahan masalah matematik dalam matematik realistik. PMR, http://staff.uny.ac.id/sites/default/files/131930135/2009aPMdalamPMR..

Trianto. (2009). Mendesain Model Pembelajaran Inovatif- Progresif: Konsep, Landasan, dan Implementasi pada Kurikulum Tingkat Satuan Pendidikan (KTSP). Jakarta: Kencana Prenada Group. 